\title{
2006-1315: THE ROLE OF INDUSTRY IN SUPPORTING EDUCATION IN ENVIRONMENTALLY RESPONSIBLE ENGINEERING
}

\author{
Andrew Borchers, Kettering University \\ Andrew Borchers, DBA is an associate professor of Information Systems at Kettering University. \\ Prior to teaching, Andy spent 21 years working as an IT manager for GM and Electronic Data \\ Systems. His academic interests include information technology, entrepreneurship and \\ environmental sustainability. Andy serves on the editorial board of Information Resources \\ Management Journal and is an associate editor of the Journal of Cases in IT.
}

\section{David Rinard, Steelcase, Inc.}

Dave Rinard, M.S., is director of Corporate Environmental Performance for Steelcase, Inc., the global leader in the office furniture industry. Dave is responsible for overseeing the company's environmental initiatives and implementing corporate environmental strategy. Dave currently serves on the board of directors of the West Michigan Sustainable Business Forum and on the advisory boards of the University of Michigan's Center for Sustainable Systems, the Aquinas College Sustainable Business Program, and the Kettering University Industrial Ecology Program.

\section{Trevor Harding, Kettering University}

Trevor Harding, Ph.D., is associate professor of Industrial and Manufacturing Engineering at Kettering University where he teaches courses in engineering materials and manufacturing. Dr. Harding's research interests include wear phenomenon in orthopeadic implants, ethical development in engineering undergraduates, and pedagogical innovations in environmental education. Currently, Trevor serves on the ERM Division Board of Directors and on the Kettering University Center for Excellence in Teaching and Learning Advisory Board.

\section{Terri Lynch-Caris, Kettering University}

Dr. Terri Lynch-Caris, Ph.D., P.E., is an Assistant Professor of Industrial and Manufacturing Engineering at Kettering University. She serves as the Co-PI for the NSF project titled "Development of a Course in Environmentally Conscious Design and Manufacturing for Undergraduates" and will team-teach the course once developed. Her areas of interest in teaching and research include ergonomics, statistics, and work design. She also serves as the treasurer for the Industrial Engineering Division of ASEE. 


\title{
The Role of Industry in Supporting Education in Environmentally Responsible Engineering
}

\begin{abstract}
Achievement of a sustainable future implies a collaborative effort between a variety of stakeholders including industry, government, and academia. We are traveling in unfamiliar waters where the course is not always clear and the goals are sometimes daunting. To develop the environmental wisdom we need to help us know the "right answers" we must bring together the knowledge we get from our academic pursuits with the experience we obtain through trial and error. Bringing together the academic world and the business world not only helps us solve the immediate engineering need, it more importantly builds a partnership that will produce greater lasting value through students (future employees) who are attuned to the market demands for improved environmental performance in both business practices and products.

This paper describes a new collaborative effort between Steelcase, Inc. and Kettering University that will prepare future engineers, managers, scientists, and policy makers for a workplace that places greater emphasis on conducting business within a framework of environmental and social responsibility. Since its founding in 1912, Steelcase, Inc. has approached its business from a "values driven" perspective focused on the underlying premise of how a responsible business should conduct itself. As such, Steelcase Inc. has been a leading company in promoting sustainable business practices both within the corporation and among a variety of other constituents. Kettering University (formerly GMI Engineering and Management Institute) has been preparing engineers and managers for the workforce since 1919, emphasizing the importance of leadership, integrity, and practical experience as the keys to success in the workplace. Together these organizations, along with other partners, are committed to demonstrating the practical need for enhanced education in issues of sustainability and social responsibility.
\end{abstract}

Funding for this project comes from the National Science Foundation DUE-0511322.

\section{Introduction}

Industry more than ever is facing challenges in the globally competitive marketplace. Thomas Friedman in his book The World Is Flat [1] talks about the forces that are changing the competitive landscape and the need for business and society to innovate more than ever to stay competitive. Friedman also highlights the need for increased learning and skill development as a way to survive in this rapidly changing and competitive climate.

Friedman cites statistics showing a significant decline in US students pursuing science and engineering educations. In a New York Times article [2] Friedman quotes a joint report of the National Academy of Sciences, the National Academy of Engineering and the Institute of Medicine that says: "Having reviewed the trends in the United States and abroad, the committee is deeply concerned that the scientific and technical building blocks of our economic leadership are eroding at a time when many other nations are gathering strength. We are worried about the future prosperity of the United States. We fear the abruptness with which a lead in science and 
technology can be lost and the difficulty of recovering a lead once lost -- if indeed it can be regained at all." If it continues, this loss of creative horsepower will stifle innovation and put the competitiveness of US firms in serious jeopardy.

At the same time, we are seeing global environmental issues take on increasing significance putting pressure on our resource availability and our life support systems. The growing population coupled with rapid industrialization in these developing nations will increase these pressures to design and produce the products and services we all use in a more sustainable way.

Many examples of the shift to more sustainable product life cycles exist. European automakers, for example, face auto recycling requirements [3] that will soon emerge in the U.S. Office furniture makers face similar challenges in using environmentally friendly practices and materials. One author [4] notes that "sustainability may be the central element of the most successful steps in addressing environmental concerns" in the office furniture market. As a practical matter, for example, the vast majority of requests for proposal in this market require environmental responses.

Engineering organizations have recognized the need to address sustainable economic development, yet curricular changes are only beginning to take place. According to the National Academy of Engineering, the growing environmental crisis means that "Engineering practices must incorporate attention to sustainable technology, and engineers need to be educated to consider issues of sustainability in all aspects of design and manufacturing" [5]. Yet many universities like Kettering University do not offer meaningful instruction in this area, and what does exist tends to emphasize air, water, and soil pollution rather than the environmental dimensions of manufacturing and product design [6].

Industry / academic partnerships are a creative way to address these pressures. By creating partnerships, both parties seek to raise awareness of the challenges business and society face and to harness the creative talents of the next generation of engineers in solving these issues.

\section{Kettering Industrial Ecology Team (KIET)}

Late in 2003 a group of faculty at Kettering University (formerly GMI Engineering and Management Institute) in Flint, Michigan began meeting to study the topic of industrial ecology. Kettering has a long history of close cooperation with industry and currently works with some 600 co-op employers in its undergraduate program. All undergraduate students are required to complete significant work experience in addition to academic studies in order to earn engineering, science or management degrees.

As KIET evolved through 2004 and 2005, it came to include a number of parties. Initially, faculty representatives from all Kettering University departments joined in the effort. Engineering faculty logically fit in the team given their focus on teaching engineering design, manufacturing processes and material selection. Science faculty, particularly in environmental chemistry, added yet another dimension to the team. Faculty from liberal studies brought a focus on ethics and industrial history. Last, business faculty added another key dimension, namely that 
students need to understand the economic consequences and learn to account for the life cycle cost of various process and product designs.

Early on KIET recognized the need to develop a broad based community to support its efforts. In addition to Kettering faculty, KIET identified academic experts from other institutions to work with the team. KIET also recruited a group of industry experts from its base of co-op employers. In particular, several members came from the automotive and office furniture industries as these are major employers of Kettering students and operate in close proximity to Kettering's campus. KIET also recruited Kettering students and university personnel in the advancement area to round out the team.

\section{KIET Activities}

In order to advance the study of industrial ecology at Kettering University, KIET began a number of activities. These activities reinforce each other.

\section{Speaker Series}

One of the early success stories for the group came in the form of visiting speakers and offcampus tours. In bringing speakers from industry to campus, KIET discovered a latent interest on the part of many Kettering students in the field of industrial ecology. KIET schedules four speakers a year, one for each 12-week term. To date this speaker series has generate wellattended lectures by students. Surveys of attendees supports the notion that industrial ecology holds great interest with undergraduate engineering students. These speakers are able to reinforce the message that faculty are beginning to communicate in the classroom, namely that engineers and managers not only have to create products that meet functional and marketing demands, they must also create products with smaller environmental footprints. At the same time that products are environmentally sensitive, they must be profitable in the competitive marketplace.

\section{Course Development}

Probably the most significant effort that KIET is involved in comes in the development of curriculum. With advice from the KIET advisory board, faculty at Kettering University are developing a combined senior level and graduate level course in industrial ecology. The National Science Foundation is funding this effort under a three year CCLI grant.

The KIET, working with their advisory board, determined that a useful starting point for this project was the Ford Motor Company PAS (Partnership for Advanced Studies) program. In particular, KIET believes that the PAS module "Closing the Environmental Loop" is an excellent base for adaptation into a university level course. Ford's experience in high schools with PAS showed it to be effective in building interest in STEM (Science, Technology, Engineering and Mathematics) among high school students, especially female and under-represented minorities.

After discussion with the KIET advisory board and a thorough review of the literature and the Ford PAS curriculum, KIET identified the following course learning objectives: 
1.) Understand the historical, social, legal, and ethical issues underlying the environmental impact of goods and services.

2.) Evaluate life cycle analyses of products and/or processes and propose strategies for minimizing environmental impact while still meeting design and economic requirements.

3.) Conduct a material selection with the goal of reducing the environmental impact of a product and/or process while simultaneously reducing material costs.

4.) Employ appropriate tools to evaluate the environmental impact of a manufacturing process and recommend actions to reduce both this impact and production costs.

5.) Analyze and propose changes to a product design that result in enhanced recycling, reuse and/or remanufacturing capabilities with consideration of the economics of these activities.

6.) Identify the relative merits of various approaches to industrial ecology within a corporation.

7.) Demonstrate enhanced critical thinking through exhibiting successful application of problemsolving strategies, high intellectual standards, and the traits of master reasoners.

KIET is designing a six module course to accomplish the objectives listed above. The intent in developing this course in modular format is that Kettering University may elect to reconfigure and use these modules in multiple venues, including continuing education for industrial clients. Kettering faculty will teach the modules using motivating case studies and active learning strategies. These methods have numerous benefits including motivating students to learn, increasing knowledge transfer [7], encouraging active learning [8] and introducing ambiguity into decision making [9].

There already exists a rich body of case studies in the environmental areas. KIET will select cases from the existing body and develop new case studies working with our industrial partners. As an example, the Ford PAS project uses the life cycle of a tennis shoe to appeal to students. Cases on Starbucks Coffee [10] and McDonald's hamburger wrappers [11] are other examples that students can easily identify with and that illustrate the complex tradeoffs of environmental, financial and public relations factors that organizations face.

The six modules for Kettering's new course include:

1.) Technology, the environment and industrial ecology. In this module students will be introduced to the broader historical, social, and ethical dimensions of industrial activity, paying particular attention to environmental impacts. Discussion of the need to move towards a sustainable society will be followed by introduction of the notion of industrial ecology and sustainable business practices. Students will also be introduced to basic environmental science and specific environmental performance metrics.

2.) Life-cycle concepts and assessment. This module presents students with the notion that environmental impact extends beyond production to include material extraction, product use, and end-of-use strategies. Students will discuss life-cycle stages for a variety of example products. Strategies for assessing the impact of each life-cycle stage will be presented and the students will explore the advantages and challenges associated with each.

3.) Material selection strategies and requirements. In this module, students will be introduced to environmental impact measures, industrial standards and guidelines, decision-making strategies that can be used for material selection, and computer tools. 
4.) Process design and improvement. Students will be introduced to methods of identifying the most damaging part of the process flow through material and energy balances. Common practices for reducing energy consumption and waste will be discussed. In addition, strategies for environmentally sustainable product packaging and delivery will be presented.

5.) End-of-use strategies. This module addresses strategies and challenges associated with reducing the environmental impact of a product after it has been used by a consumer or business. Discussion will focus on re-use, remanufacturing, recycling, and disposal options. Design for recycling tools will be demonstrated and practiced on real products.

6.) Environmentally responsible management. This module will present current best practices in promoting design for the environment within the corporation. In addition, the module will introduce students to current trends in environmental management systems, green supply chains, lean manufacturing, and total cost accounting.

\section{Conclusion and Future Steps}

Environmentally responsible engineering is an emerging topic of vital interest to engineering educators and to employers of engineering graduates. This field is inter-disciplinary by its very nature, requiring students and practitioners to consider multiple objectives simultaneously. Moreover, as an emerging field of practice, students and faculty need to work closely with industrial partners to ensure relevance and currency. Kettering University's KIET effort has brought together experts in the academic and the industrial world to create appealing academic experiences for undergraduate students.

Beyond the initial steps of bringing speakers to campus, creating a community of interest and creating a single combined undergraduate/graduate course, KIET has many more roads to travel. First, KIET can develop additional courses to provide more depth of study. Such efforts are likely to be limited, however, given the already "packed" undergraduate engineering curriculum. Second, KIET may find greater success in introducing industrial ecology topics in traditional engineering and science courses. Third, Kettering University as a co-op school can identify coop opportunities for students that need environmentally oriented engineers. Fourth, Kettering can work with industry partners in sponsored research and student focused design projects and competitions. Fifth, KIET can use material from its new academic course in offering continuing education to corporate clients. Finally, KIET can develop outreach programs focused on the environmental and social impacts of science and technology. For example, KIET has already identified interested groups wanting to teach industrial ecology at the K-12 level. This is especially important as Kettering University works to attract students, particularly women and under-represented minorities, to the engineering profession.

\section{References}

1 Friedman, T. The World is Flat, Farrar, Straus and Giroux, New York, 2005.

2 Friedman, T. "Keeping Us In The Race”, New York Times, October 14, 2005. 
3 Kimberley, W., "European Vehicle Manufacturers Face Recycling Requirements"

Automotive Design \& Production. Vol.116: 8; 2004, pg. 20-22.

4 Rowh, M. "Inside the Sustainable Office”, Office Solutions, Vol.22:3 May/June 2005, pg. 22-25.

5 National Academy of Engineering, "The Engineer of 2020: Visions of Engineering in the New Century". The National Academies Press, Washington, D.C.2004.

6 Powers, S. E., Zander, K. Theis, T.L. and Maclean H. "Incorporating Industrial Ecology and Sustainability Concepts into Environmental Engineering Courses." Workshop presented at the AEESP/AAEE 2002 Education and Research Conference. Clarkson Center for the Environment, 2002.

7 Bocker "Is Case Teaching More Effective than Lecture Teaching in Business Administration? An Exploratory Analysis." Interfaces, Vol 17:5, 1987, pp. 64-72.

8 Kenney, S. J. "Using the master's tools to dismantle the master's house: Can we harness the virtues of case teaching?" Journal of Policy Analysis and Management, Vol 20:2, 2001.

9 Banning, K.C. "The Effect of the Case Method on Tolerance for Ambiguity." Journal of Management Education, Vol 27:5, 2003.

10 Austin, J. E. "Starbucks and Conservation International, Video", Harvard Business School Publishing, Boston, 2003.

11 Svoboda, S. "McDonald's Environmental Strategy" retrieved 1/18/06 from http://www.umich.edu/ nppcpub/resources/compendia/CORPpdfs, 1995. 